INTERNATIONAL JOURNAL OF FILM AND MEDIA ARTS (2021) Vol. 6, №. 3 pp. 114-131

(C) 2021 BY-NC

ijfma.ulusofona.pt

doi: 10.24140/ijfma.v6.n3.08

\title{
SHADES OF \\ INVISIBILITY
}

SALLY PEARCE* 
Sally Pearce is a third year PhD by Practice student based at Wolverhampton University. Her research is concerned with women's auto-ethnographic animation practice. Her short animated and mixed media films have screened at Festivals around the world, including for instance, Annecy, Shanghai, Uppsala, Chicago, St Louis, winning a number of awards including a Bafta. Since 2009 she has been working on her long form mixed media project Chernobyl Journey. Her article 'Knowledge Production as Process in Arts Practice as Research' will be published in the upcoming volume 9 of the Intellect Journal 'Animation Practice, Process and Production'. She has delivered academic papers in a number of symposiums and conferences:

* Society of Animation Studies Annual Conference, 2021 Tulane University, New Orleans 'Animation Practice as Research' Symposium, Manchester, April 2021.

* 'Ecstatic Truth 52020 'The Age of the Absurd' in association with Under_The_Radar Festival. Vienna

* 'The Society for Animation Studies Annual Conference, 2019'. Universidade Lusófona, Lisbon, 17th-21st June 2019.

* The 'Female Agency and Subjectivity in Film and Television Conference' Bilgi University, Istanbul, 11th-13th April 2019.

* The 'Crafty Animator Conference' Rich Mix Cinema, 7th September 2017.

* 'Animation and Memory' Radboud University, Nijmegen. 22-23rd June 2017.

* 'Ecstatic Truth 2 'Lessons of Darkness and Light', 27th May 2017.

\section{Corresponding Author}

Sally Pearce

s.p.pearce@wlv.ac.uk

Wolverhampton University

Wulfruna Street

Wolverhampton

WV1 1LY

United Kingdom 


\begin{abstract}
Shades of Invisibility is an ongoing experimental artist's documentation of my practice in making Chernobyl Journey, an activist film that I have been working on for twelve years. In Chernobyl Journey live action tells the story of my four trips to the Chernobyl Exclusion Zone between 2009 and 2015 in search of rare Przewalski Horses, while animation is used to subversively unravel this apparently straightforward and chronological story backwards, tracing my fascination for the Exclusion Zone back to memories of an acute and life-changing illness in my own timeline from May to August 1986. In the film, animation is used not only to portray my inner private world of sensations, emotions and memories, but also to trace the slow process of arriving at self-knowledge through unravelling invisibilities of a very external and political nature. However, it is not the animation itself that makes the film experimental and subversive, but the way in which the animation is intimately woven into the live action footage. Through methods of compositing and blending, a counter historical narrative is inscribed into the fabric and the forbidden spaces of the two landscapes my auto-ethnographic story inhabits. As well as providing an outlet for my counter historical auto-ethnographic story, Chernobyl Journey also debunks the myth that nature will spring back like a lightly trodden on blade of grass, even after the worst excesses of human exploitation, extraction and environmental disaster. Shades of Invisibility is informed and inspired by my reading of New Materialist texts, in particular Jane Bennett's 'Vibrant Matter'. In the text I attempt to explore the efficacy of agencies other than my own will upon my art, using invisibility as a linking theme to create a network of interlocking pathways into subject matter that is dense, multi-layered, interdisciplinary, complex and sometimes politically taboo. My approach to documentation is activist in itself, as it questions the hylomorphic and anthropocentric world view that underpins auteur theory. I argue that this model of creativity based on the unrestrained and unaccountable power of the human individual's will mirrors the neo-liberal model of unrestrained extractive capitalism that is contributing so much to our present reality of climate crisis, loss of species diversity and global injustice.
\end{abstract}

Keywords: Activist, Chernobyl, Invisibility, Vitalism, Animation. 


\section{Introduction}

This article is part of my ongoing experimental artist's documentation of Chernobyl Journey - a work in progress long form mixed media documentary that I have been working on since 2009. I call my documentation Shades of Invisibility because the film's subject matter deals with multiple layers of invisibility, and also because the film's past, present and future production and presentation is entangled in multiple layers of invisibility. Inspired by vitalist texts, such as Jane Bennet's Vibrant Matter, I attempt to explore the efficacy of agencies other than my own will upon my art, using invisibility as a linking theme to create a network of interlocking pathways into subject matter that is dense, multi-layered, interdisciplinary, complex and sometimes politically taboo. This attempt is at the same time playful but serious, a calculated letting go of the self, becoming lost, embracing failure that may, or may not, lead to an enhanced way of being a maker in the world. It is, as Judith Halberstam states in The Queer Art of Failure about "failing well" and "learning how to fail better" (Halberstam, 2011, p. 24). Both the film itself, and this documentation of it, can be described as activist. In the text that follows I explain how the film's activism became and is still becoming; I explain why I consider the experimental approach to artist's documentation that this article represents to be activist in itself, and I take the reader on a haptic and experiential tour of my film making practice using the concept of invisibility as a unifying principle. At the end of the article there is a more detailed and traditional synopsis and treatment of Chernobyl Journey that can be read at any point.

\section{Chernobyl Journey}

In Chernobyl Journey live action footage tells the story of my four trips to the Chernobyl Exclusion Zone between 2009 and 2015 in search of rare Przewalski Horses, while animation subversively unravels this apparently straightforward and chronological story backwards, tracing my fascination for the
Exclusion Zone back to memories of an acute and life-changing illness in my own timeline from May to August 1986. The illness occurred after I had spent a weekend walking in the rain that brought Chernobyl ash down on the mountains of my home. When, nearly thirty years later, I asked to see my medical notes for this period they were found to be missing, making my memories the only record of my illness. A dated consultant's letter confirmed that my notes were already missing in February 1987.

Chernobyl Journey did not start life as an activist film. In fact, my intention when I first flew to Kiev, in March 2009, as I was drawing my horse protagonist in my notebook on the plane, was to make a fiction from fact film aimed at older children. As narrated at the beginning of the film, as soon as I entered the Chernobyl Exclusion Zone I knew I was making a documentary, but many years would pass before I understood why I needed to make a documentary. The fictional character I was creating on the plane to Kiev in March 2009 survived the switch to documentary and becomes my enigmatic guide in the six-year search for self-knowledge that the film depicts (Fig. 1).

In the film, animation is used not only to portray my inner private world of sensations, emotions and memories, but also to trace the slow process of arriving at self-knowledge through unravelling invisibilities of a very external and political nature. Paint on glass is my primary animation technique although a variety of other techniques are employed. However, it is not the animation itself that makes the film experimental and subversive, but the way in which the animation is intimately woven into the live action footage. Through methods of compositing and blending, a counter historical narrative is inscribed into the fabric and the forbidden spaces of the two landscapes my auto-ethnographic story inhabits. In the introduction to Pervasive Animation Suzanne Buchan explains how the book's cover image (a still from Cathy Joritz's film Negative Man (1979) in which 


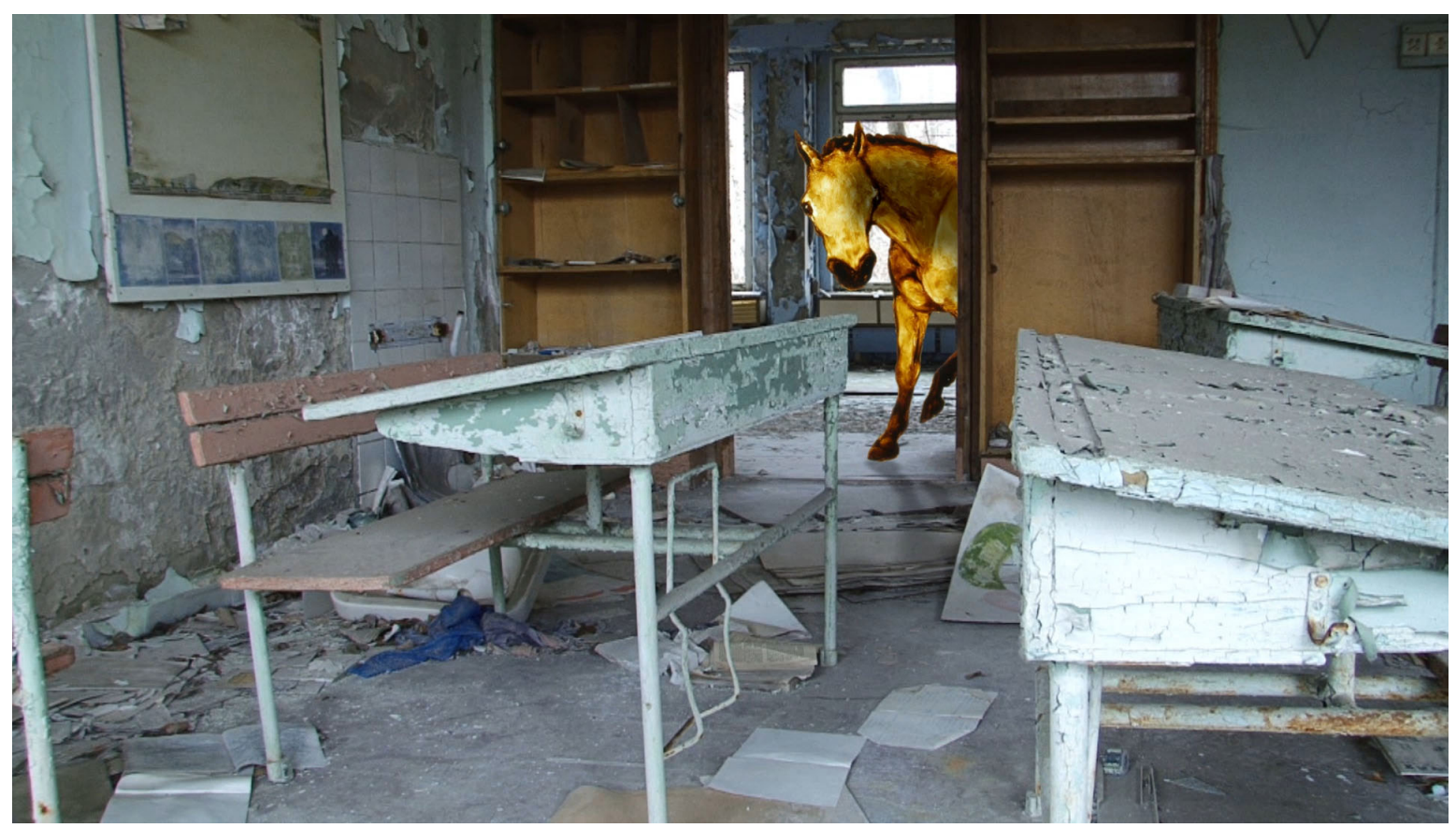

Fig. 1 Chernobyl Journey Still.

animation is scratched directly onto live action film) was chosen because the animation "...complicates live action film with invasive animation..." (Buchan, 2013, p. 10). In Chernobyl Journey, although it is the relation between live action and animation that creates subversion, the dynamic is more reciprocal, the animation and live action complicate and invade each other, the mixed media creating multiple layers of meaning that are not present at all in the live action or the animation alone. In Cartoon Animals and Natural Philosophy, his article in Pervasive Animation, Thomas Lamarre describes in detail this reciprocal dynamism between character animation and background as it occurs even in traditional cel cartoon animation, arguing that "... compositing affords a key to evaluating the overall coordination of forces in animation, and in that respect it takes priority over character animation..." (Lamarre, 2013, p. 123)

\section{Shades of Invisibility}

My documentation of Chernobyl Journey is activist as well as experimental as, by exploring the body of work I call my own through the efficacy of many different kinds of agency upon it, I suggest an alternative to the hylomorphic model of creativity that places only the individual artist's mind and will at the centre of artistic production. As Tim Ingold explains "...from the Greek hyle (matter) and morphe (form). Whenever we read that in the making of artefacts, practitioners impose forms internal to the mind upon a material world 'out there', hylomorphism is at work." (Ingold, 2013, pp. 20-21) The reason why a hylomorphic interpretation of creativity is something to resist, something to suggest alternatives to, is that it is purely anthropocentric - it places the human will at the centre of making and attributes agency only to the human mind, 
treating everything that is not human mind as either inert, or, if a living organism that is motivated by something at least analogous to a brain, as instinctual. This model of creativity, based on the unrestrained and unaccountable power of the human individual's will, mirrors and confirms the neo-liberal model of unrestrained extractive capitalism that is contributing so much to our present reality of climate crisis, loss of species diversity and global injustice.

The idea of the film auteur refines the hylomorphic/anthropocentric account of artistic production to the point that even other human beings become inert material to be manipulated by the detached and independent individual will, promoting an image of the artist as a kind of top predator, which has the effect of suppressing diversity and maintaining the status quo of white male hegemony. I would like to suggest an alternative idea of the artist as a filter feeder - a basking shark, a baleen whale, krill, or tunicates, bivalves, sponges and jelly-fish - a vastly diverse range of creatures from microscopic to huge, leading utterly different lives from each other but at the same time utterly dependent upon each other. Artists as marine filter-feeders are always floating in a cultural soup, constantly drawing in influences, constantly contributing back to the cultural soup and constantly moved and affected by infinite variables within endlessly complex interlocking ecologies. In such a deeply rich and diverse environment, the individual artist matters, but only as part of the ecologies that make the mattering possible.

I am often asked to explain, as part of the process of taking a PhD, how my work is going to have impact. The idea that work must 'impact' fits in with a 'top predator' model of the artist. I prefer the idea of non-impactful influence - as a single starling influences 'the breeze created by a thousand furiously flapping wings' (Gale, 2018, p. 22) at the heart of a murmuration. In this article, I have tried to displace my personal will and agency from their usual position at the centre of artist's documentation, showing my activities instead as part of a web of events, organisms, materials, properties, states, collaborations and infrastructures that all have a kind of agency, or efficacy, even if they are very unlike human thought. I do not master this tangled world that drives my work, I am an engaged part of it, and the work I call mine ensues from the engagement.

\section{Contextualisation}

This approach to documenting my work has a theoretical context in the project of New Materialism - a multi-disciplinary movement involving many players coming from a diverse range of philosophical traditions. There is nothing new about Materialism in Western philosophy. Jane Bennett lists Epicurus, Lucretius, Hobbes, Spinoza, La Mettrie, Diderot, Marx, Althusser and Deleuze as sources of 'historical lines of thought in which materiality is figured not as inert or even passively resistant but as active and energetic' (Bennet, 2010, p. 47), before going on to discuss the vitalism of Driesch and Bergson. Other articles in New Materialisms, Ontology, Agency discuss, for instance, Aristotle, Nietzsche, Heidegger, Merleau Ponty, De Beauvoir, Irigaray, Derrida, Foucault - it is clear that old materialism is an important and pervasive historical strand in the fabric of Western thought. The New in New Materialism refers to a multi-disciplinary movement that attempts to find a way of framing materialism that can accommodate and respond to the loss of certainty that has occurred in the modern and postmodern world. In the Newtonian age bodies with boundaries could be relied upon to relate to each other through laws of cause and effect with reliably predictable results. This certainty, that lead to political and social organisations that appeared natural, has been lost as barriers between, for instance, self and environment, human and machine, human and animal have become increasingly porous.

As Diana Coole and Samantha Frost describe in the introduction to New Materialisms, Ontology, Agency and Politics (2010) the loss of perceived solidity, perceived boundaries, perceived selfhood, and perceived human agency and control in the postmodern world has occurred across disciplines. In the physical sciences atomic behaviour has been found to consist of 
"emergence, attraction, repulsion, fluctuation, and shifting of nodes of charge 'demonstrating' none of the comforting stability or solidity we take for granted" (Coole \& Frost, 2010, p. 11) whilst in the physics of subatomic particles "one finds an even more quixotic and elusive sense of matter". (2010, p. 11) Chaos theory, in which "apparently random effects have an extremely complex, non-linear provenance" (2010, p. 13) and complexity theory which emphasizes "unpredictable events that can catapult systems into novel configurations" (2010, p. 13) have transformed ideas about patterns of movement and have also been highly influential in destabilizing existing theories of socio-political and economic organisation, which can now be seen as "emergent systems that move with a superficially chaotic randomness that is underlain by patterns of complex organisation..." (2010, p. 14) In the natural sciences, boundaries have become increasingly porous, between organisms, between animal, plant and mineral, between lively and not alive. We are ourselves very affected by this porousness - we are found to be not fortresses composed only of self, but rather a loose affiliation of minerals and chemicals and multitudes of other organisms; whilst through medical procedures, through ingestion and through the entanglement of technology and the digital in our daily lives we are all effectively cyborgs. "Our machines are disturbingly lively and we ourselves are disturbingly inert" (Haraway, 1997, p. 152).

Vitalism - in which agency is attributed not only to humans, but to non-human animals and plants and dubiously lively things like vegetables, fungus or bacteria and to completely unlively things such as minerals, chemicals and technologies - is a controversial aspect of materialism. Attributing agency to things like the electricity grid, trash and food, as Jane Bennet does in Vibrant Matter: a political ecology of things (2010) can seem like a sleight of hand, a wriggling out the closed system of humanist Cartesian duality by anthropomorphizing non-human and apparently non-lively things to also possess agency. Tim Ingold criticizes Bennet's concept of Thing-Power: "the curious ability of inanimate things to animate, to act, to produce effects dramatic and subtle." (Bennet, 2010, p. 6). He argues that "the entire question of agency rests on a false premise." (Ingold, 2013, p. 96) and goes on to state "humans do not possess agency; nor for that matter, do non-humans. They are rather possessed by action." (Ingold, 2013, p. 97). Karen Barad also avoids attributing anything analogous to agency to matter, but argues cautiously to allow "matter its due as an active participant of the world's becoming."

But I think Bennet sees her concept as a political device rather than an ontological argument. "We need to cultivate a bit of anthropomorphism - the idea that human agency has some echoes in nonhuman nature - to counter the narcissism of humans in charge of the world." (Bennet, 2010, xvi). She also states, "What seems to be needed is a certain willingness to appear naive or foolish...." (Bennet, 2010, xiii) and to "....suspend suspicion..." (Bennet, 2010, xvii). It is in this spirit that I attempt to document my art project as a "human-nonhuman working group" (Bennet, 2010, xvii) or "assemblage" (Deleuze, Guattari, 1987/2013) in which I am a constituent part along with, for instance, dust or photons. The attempt is not successful, Cartesian mind/body, mind/matter duality has become so strongly normalised any other approach to thinking about ourselves in the world seems unnatural. "For there is an apparent paradox in thinking about matter: as soon as we do so, we distance ourselves from it, and within the space that opens up, a host of immaterial things seem to emerge: language, consciousness, subjectivity, agency, mind soul; also imagination, emotions, values, meaning," (Coole and Frost, 2010, p. 2). My attempt to think of my artistic activity as a part of the world rather than an imposition upon the world is bound to fail, but it is the effort to think differently about myself in the world that matters here, people need to think differently about the world.

I am also of course influenced by very many film makers and animators and artists. In this article, I identify with a particular context of films that use animation to critique power structures by seeing them through the lens of the personal and private. For instance, Faiyaz Jafri's response to witnessing the collapse of the twin towers in This Ain't Disneyland (2015) 


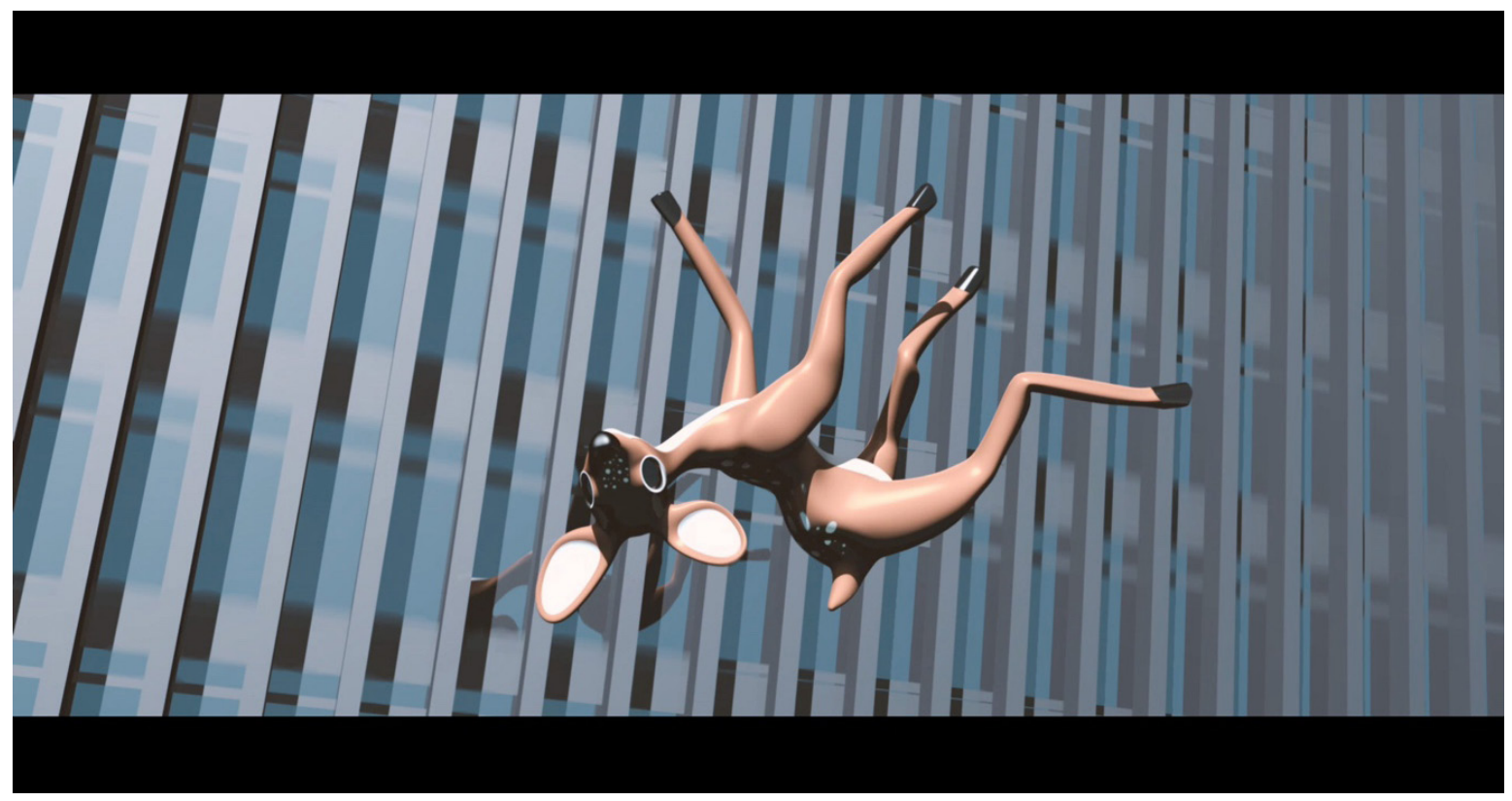

Fig. 2 'This Ain't Disneyland' F. Jafri. 2015.

(See Fig. 2), N'gendo Muuki's account of the effect of colonial values on African women in Yellow Fever (2012), Ruth Lingford's exploration of the Trump presidency through dreams in Trump Dreams (2018), Stacy Bias' critique of the commercialisation of the space the body takes up in Flying While Fat (2016), and Nina Paley's history of Israel told through the prism of her relationship with her father, in Seder Masochism (2018). These films all use animation specifically to make explicit how very political the very personal actually is.

\section{Invisibilities}

In this documentation, I present my work as a complex web. If I am a spider in this web, the web is weaving me as much as I am weaving it. The web itself is endless, I am perhaps only aware of a fraction of the strands and from those I had to select what I have space to discuss in this article The following text is therefore a time bound and limited snapshot of my work in progress film at a given moment in time, but the passing of that moment in time has already radically changed everything, the next snap-shot documentation of the film will be very different, the now this snap-shot attempted to capture is lost, it no longer exists. Now is always invisible.

There is an element of word game in my use of the concept invisibility. What does grieving have in common with radiation? What does Covid-19 have in common with animators' labour? What property is shared by memory and diabetes? The game is facilitated by an ambiguity in the meaning of invisibility, which the Cambridge Dictionary defines as "the fact of being impossible to see, or of not being noticed". Invisibility can be a property or a state of mind, as a state of mind invisibility is ubiquitous because everything we are not actually seeing at any given time is invisible. But surrendering to the word game, allowing myself to be led astray by the ambiguity and ubiquity of invisibility, deliberately becoming lost, facilitates my 


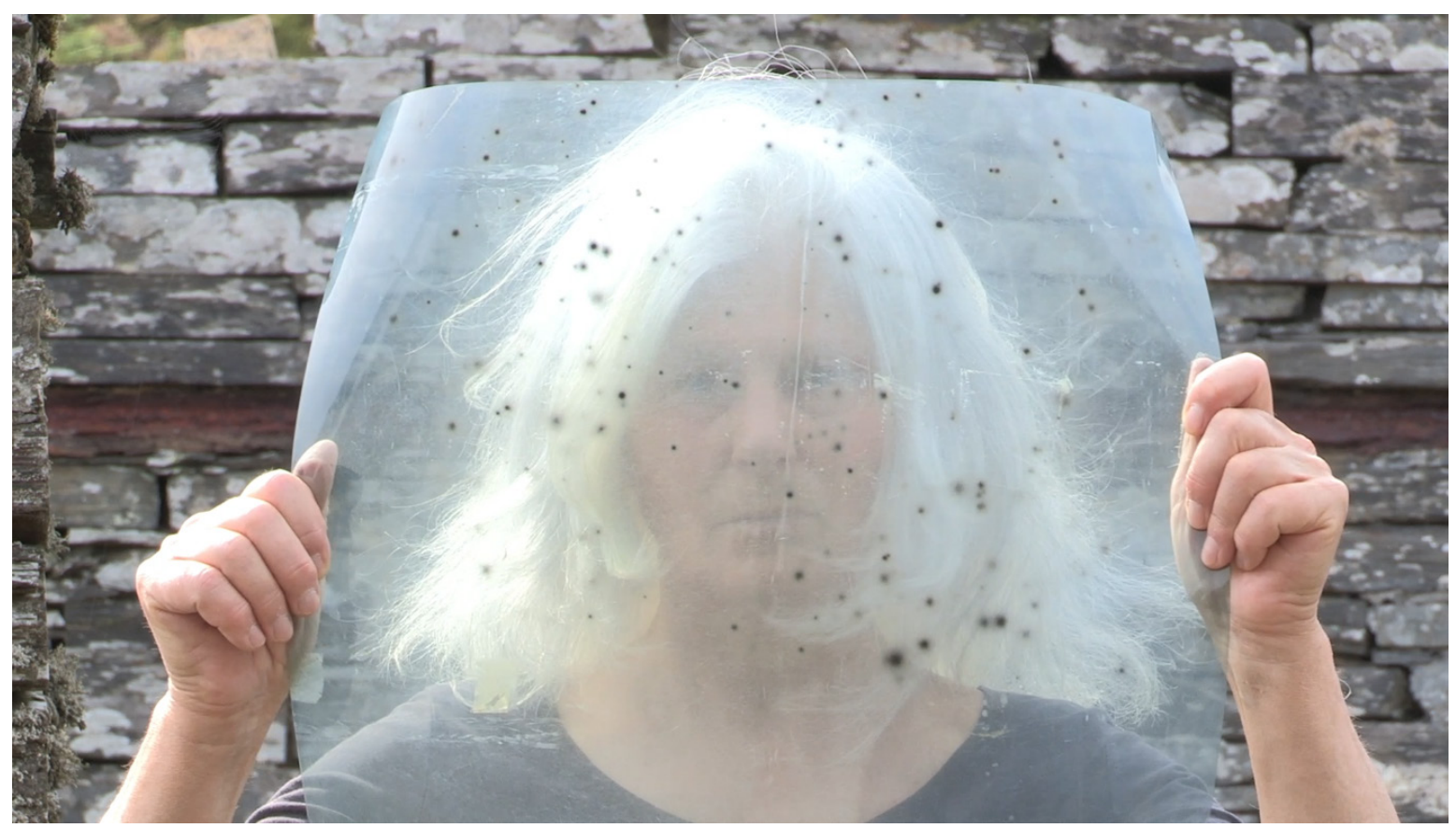

Fig. 3 The action of radioactivity on photographic film, May, 1986.

attempt to see myself as "a participant in amongst a world of active materials". (Ingold, 2013, p. 21)

\section{1: Viruses, Radiation, Vested Interests}

At thes time of writing, we are all wrestling with one manifestation of invisibility - the covid virus. We can't sense this virus in droplets in the air or on the surfaces we touch - but we are very aware of it because of an extensive and politically orchestrated infrastructure of communications that effectively makes it highly visible to us. In The Politics of Invisibility, Olga Kuchinskaya argues that political infrastructures can equally create invisibility and that the health effects of the Chernobyl disaster have been rendered doubly invisible. This is possible, even in the case of a huge wave of such effects, because knowledge of the existence of radiation and its effects has to be mediated by experts. Kuchinskaya uses the term Lay
Invisibility (Kuchinskaya, 2014, viii). If you were in a room with a source of radiation, just the same as if you were in a room with the covid virus, if you had no prior knowledge and no specialist equipment, you would be completely unaware of the danger.

In milder doses, the effects of exposure to radiation are likely to be delayed by many years, even not manifesting themselves until the next or a later generation in the case of DNA damage. The effects are also not specific to exposure to radiation - cancer, for instance, can have many causes. That both the actual presence of radiation, and also the connection between exposure and health effects, have to be mediated via experts within an institutional infrastructure renders public access to information easily subject to political control. Experts whose evidence is not politically acceptable do not need to be silenced in any visible way - deprived of funding and 


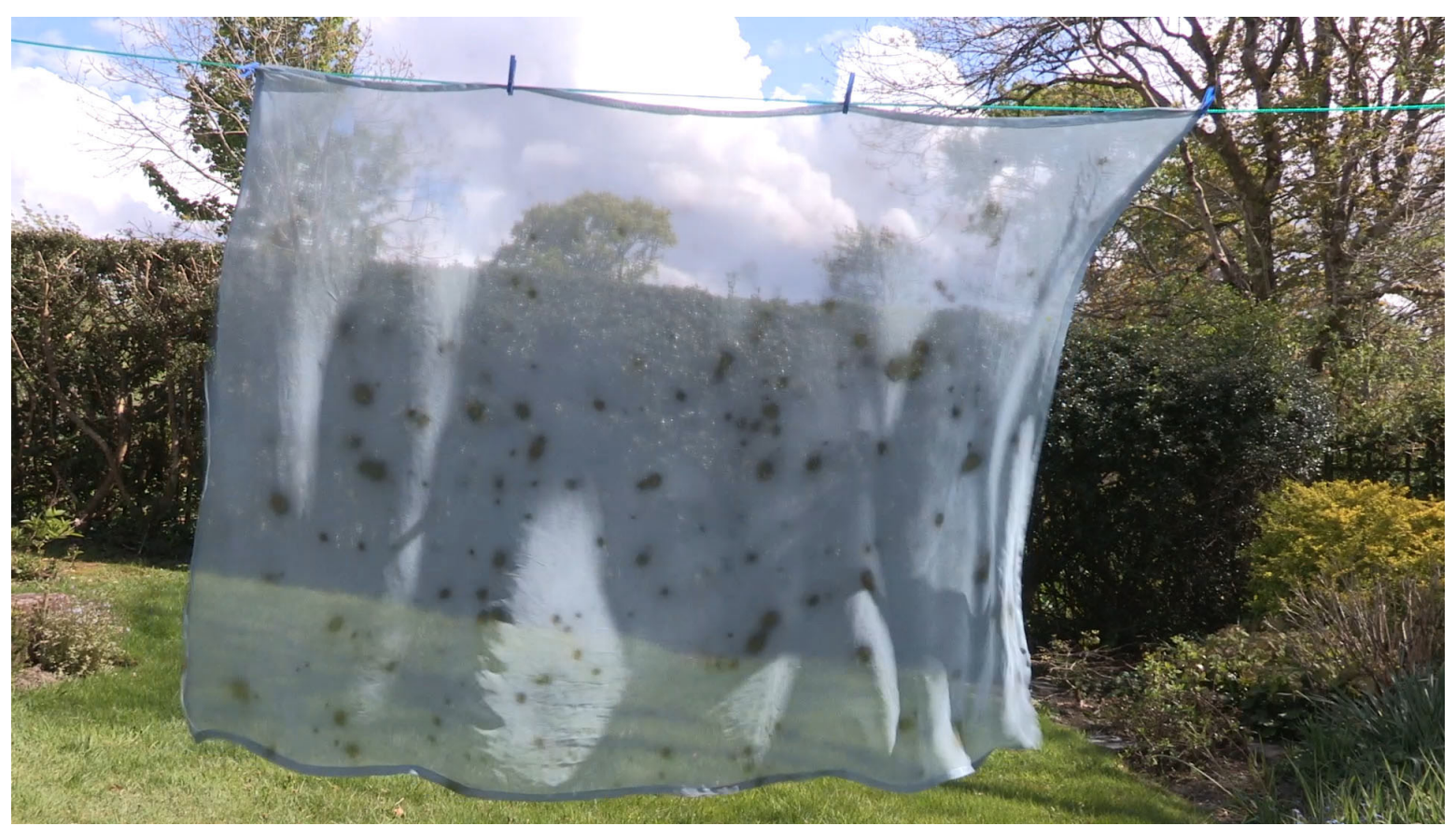

Fig. 4 A scarf printed from the film, used as an invisibility cloak in Chernobyl Journey.

of platforms for dissemination of their research, they will become invisible over time. "Science, which we trust to provide us with relevant knowledge is increasingly an object of outside political pressures, especially from interested industries, creating areas of uncertainty and ignorance" (Kuchinskaya, 2014, p. 7). Evidential data can quickly become invisible, especially if it is not actually collated in the first place.

The scarf (Fig. 4) I show here is printed from a film (Fig. 3) which I acquired from a retired physicist, who was a regional radiation safety officer in the UK in 1986 . The image was made by lying photographic film on the dress of a British woman who had been on holiday in Kiev on the night of the Chernobyl explosion, April 28 ${ }^{\text {th }}, 1986$. She had sat on a park bench, with her children, watching a light white ash fall. The rather beautiful starry marks record the effect the radioactive particles had on the photographic film. The physicist commented that just as there were particles on the woman's dress, so there would be particles in the woman's lungs. The contaminated clothes were destroyed, but there was a reason why the family could not be followed up and monitored for their health. Strangely this thing with almost an indexical link to the Chernobyl disaster has come into my possession - all its own network of links to other lives are invisible to me, but I almost feel it breathe when I hold it. By transferring the image to fabric I trace a fraction of its' journey backwards towards the dress of a strange woman whose life is invisible to me. I am part of the journey of this slip of photographic film, you could say it found me and not vice versa.

After reading Kuchinskaya's book (in 2015), I asked to see my medical notes for the period from April to August, 1986, a period from which I have only a very few and very strange memories. Those few memories were of being hospitalized with an 
acute illness, but my medical notes were found to be missing, invisible, for the precise dates I had asked to see. A letter from a consultant to my GP dated February 1987 revealed that the notes were already missing at that time. One of my last 'normal' memories, before the strange sequence of illness memories, is of laughing with a friend, when we found out we had been walking on the mountains in that rain that brought the Chernobyl ash down to the ground. We joked about glowing in the dark.

So, here are two manifestations of invisibility - firstly, the invisibility, to myself, of the motivation for my fascination for the Exclusion Zone. But more significantly, the invisibility behind my self-blindness, of those very profound political controls, exercised through institutions such as schools, museums and the media, and infiltrating every aspect of our community life, that lead us to censor our own thoughts, or simply to be ignorant, for the benefit of vested interests. I had not been unaware of my strange memories of illness in the summer of 1986 during the seven years I had felt compelled to visit and study the Chernobyl Exclusion Zone from 2008 to 2015. During that time I had spoken to many people about the health effects of Chernobyl in Europe and the UK. But, for seven years, I simply never made the actually rather obvious connection between my strange and life changing illness in spring, 1986, and my subsequent fascination for the Chernobyl Exclusion Zone, not even as it started to take over my life. I couldn't think that thought - not out loud.

\section{2: The Political, The Personal and The Producer/Director}

You could ask, why are you actually attempting to make a mixed media feature film without funding? Isn't this unwise? The answer (of course) is - it is complex. In his article Political Animation and Propaganda (2018), Eric Herhuth explains his text follows "two intersecting lines of enquiry (1) the animation of politics and (2) the politics of animation" (Herhuth, 2018, p. 170).
My originally (I believed) apolitically motivated project gradually became consciously political and activist as, during a protracted search for funding, the animation of politics and the politics of animation became one and I slowly realised that, with regard to the status of animals in the Chernobyl Exclusion Zone, an apolitical stance was untenable. So far as media representation goes, the Przewalski Horses in the Zone are a political cipher before they are animals. In the early days the film idea was well received, and for my first two trips to the Zone, and the first delivery of animation, I had development funding (that would now be enough to complete the film.) This is because I was first attracted to the Zone by the popular narrative of wildlife thriving in the damaged environment, I was going to tell the story of the release of rare Przewalski Horses into the Zone in the 1990s as a heart-warming tale of regeneration. This was very popular with funders. But by 2013 I had learned that the popular wildlife thriving or wildlife returning trope is a politically motivated myth. So, the already well-developed film I was seeking production funding for had moved on to a much more subtle and disturbing image of wildlife in the Chernobyl Exclusion Zone, causing all the doors to funding that had been standing enticingly open to shut.

The film didn't become activist overnight. I could not overcome my distaste for accommodating political myths for the sake of acquiring funding, but initially I just shifted the focus of the film from the world out there to the (invisible) World in Here, (Chapter title, Honess Roe, 2013, p. 106) changing the name from Chernobyl Horses to Chernobyl Journey and emphasizing my own journey and my subjective view-point, in an attempt to evade censorship (Herhuth, 2018, p. 177). I believed the personal and the political did not occupy precisely the same ground. This manoeuvre proved to be a funding disaster, the journey into myself led to a much more critically subversive position, and at the same time, gave me much stronger reasons to make the film, so I was caught on my own hook. It taught me how political the personal is. It also taught me, too late, not to attempt to make a mixed media feature 
length film on this subject. Chernobyl Journey is an activist film by default. It became activist by (invisible) degrees as, at each stage when the only sensible thing to do was to drop the film and move on to something that wasn't a film maker's dead-end, I didn't drop it.

Chernobyl Journey does already have a sort of adolescent film life, it has occasional viewings as an increasingly advanced work in progress, has a semi-visible presence in my presentations and writing and has the good will of a very small group of engaged people. But I'm not sure what the prognosis is. Are we going to be able to pull this film-organism through and release it into the world? What would made look like anyway in the context of this highly unorthodox film making process? I dream of a completion grant - but this is not particularly likely. I find there is an inverse relationship between the progress of the film towards being made in terms of being a viewable time occupying sequence of images and sound that is perhaps interesting; perhaps beautiful; perhaps even important (as some viewers have commented) - and the progress of the film towards the completion grant that is really needed to bring the film to a public audience. Having made great progress over the last few years in the direction of having the film on a timeline and privately viewable, I am now considerably further away from completion funding than I was when the film was not edited at all, as I alone, as the director of the piece as well as the sole producer, can only apply for development funding. Typically, for late-stage production or development funding, the director and producer have to be two people, making film makers like myself twice invisible.

Even if completed, an unfunded and completely independent feature film might be invisible to festival programmers, because acceptance by funders and production companies, the whole process of having gone through the system, are essential for validation. A film that has not arrived via a (politically) recognised and institutionalised process is likely to remain invisible. Continuing to make a film that faces such an uncertain future is certainly deeply unwise but it is a protest - against the cynical use of the animals themselves to distract from the destruction of their environments in the endless flood of articles and films that present the profoundly damaged and toxic landscape of the Exclusion Zone as a haven for wild life; against the obfuscation of health and safety research and information in the nuclear power industry and against the use of artist's and scientist's funding as a means of political control on the behalf of vested interests. In Toxic Bodies Nancy Langston notes that scholars "might not be able to prevent the powerful from wilfully manipulating historical narratives to stay in power" but she continues "we can and should provide counter-narratives that push back against these manipulations" (Langton, 2011, p. 166).

\section{3: Dust, Diabetes, Memory and Grief}

After discovering that my medical notes were missing for the period from April to August 1986, I had decided to use animation to make a record of my illness through animating the few strange memories I have of being ill during that period. But, I found myself blocked as my efforts to draw my memories seemed to change them and, as a I saw the memories as a kind of testament, I was confused to discover that there is such a profoundly creative aspect to the mediation even of one's own memories. After a long period of coming to terms with this, by early 2018 I was ready to animate the memories (which are themselves invisible, not only to other people, but also to myself), but I was waiting, holding on, trying to raise funds as I perceived the memories - in so far as they existed as visions at all - to be white on white and suffused with an unbearable glow. I felt unqualified to produce this look without some photographic genius to help me out. But then, I suddenly became diabetic and the effect of high blood sugar on my vision panicked me into starting work.

Dust circles invisibly in the darkened air of the room where I work. The heat of the back lit glass surface I paint on attracts it. Gradually it becomes part of the texture I am creating, 


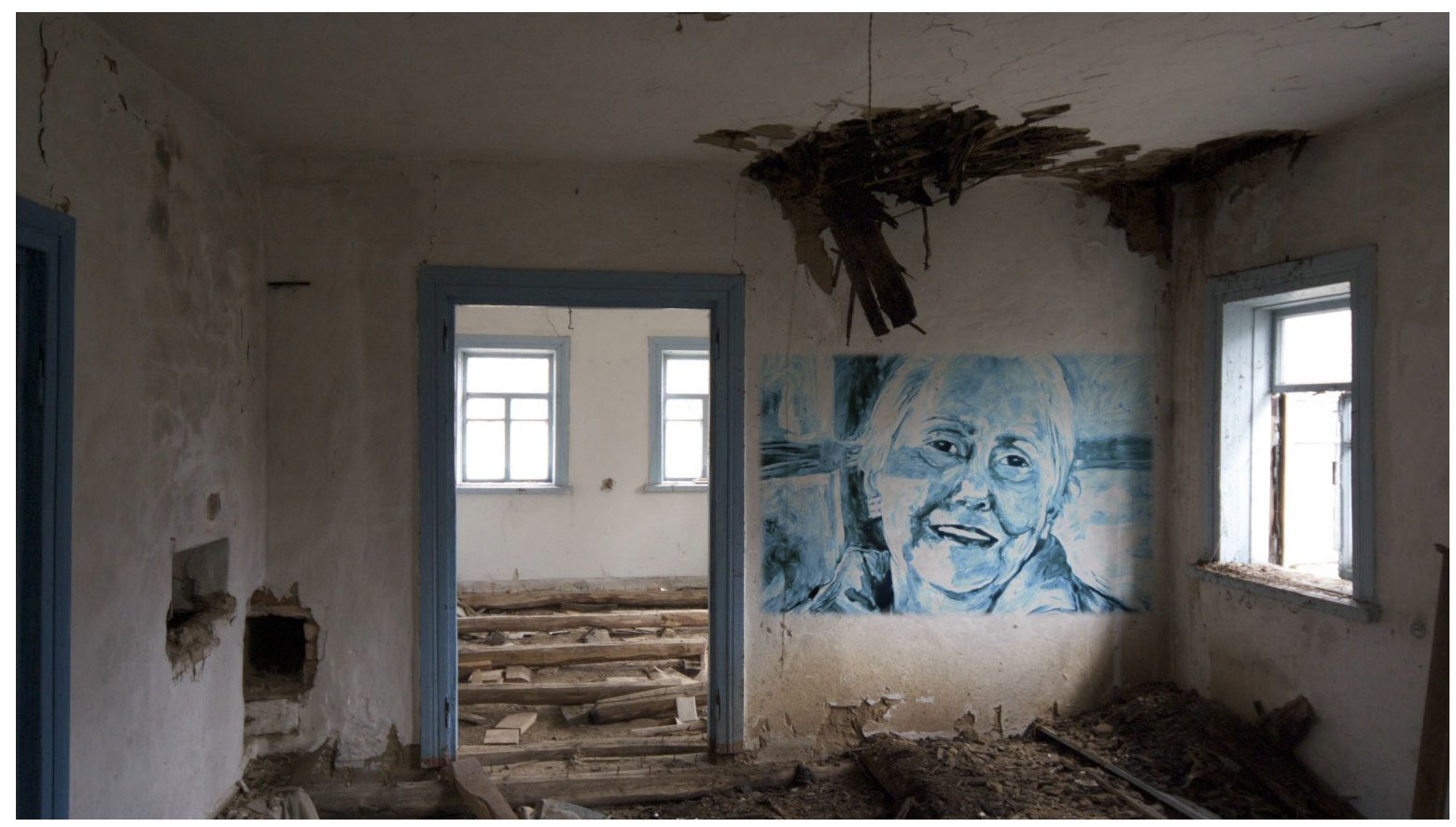

Fig. 5 Memory animation inserted into the live action as a window within a window.

blending with the marks of my fingertips. Eventually I decide the paint has become too dirty and I make a new mix, so that, in a longer shot, the rising and falling waves of dust become rhythmic, like the sea. Dirt is also one of the metaphors for radioactive contamination. I had a particular problem with the dirt in my paint when I started work on my memory animations. When I became diabetic, my eyes packed their bags and took an adventure holiday. One day I had incredibly close vision, the next day I could see birds on trees on the hilltop across the valley, but not my hands in front of my face. I worried that my sight would be permanently damaged.... started to work on my memory animations in a panic, using the resources I could afford and already had in place - cheap paint and my home-made paint on glass set up (with a 12 year old computer at the helm.) Quite quickly I realised I had a problem, the white paint was so transparent every speck of dust showed very quickly.
But, having finally started to animate these memories, I couldn't, and wouldn't, stop. After all, I rationalised, radioactivity is dirty, isn't it? Also, the dirt seemed like a projection of my diabetes - I was aware of multiple floaters affecting my vision, and my eyes themselves felt gritty. It was almost as though I'd projected diabetes onto the screen. Preliminary animated squiggles of paint that resolve into the image came about because the paint was such a brute, it wouldn't blend with the medium, I had to wrestle with it on the glass before it became malleable enough to use. There was another shock waiting for me when I had finished the first memory shot. In my diabetes induced panic I had simply forgotten that my set up is designed to produce animal characters to be composited into a 16:9 ratio image. I intended the memory animations to fill the screen, but they were the wrong ratio. The next illness memory shot I tackled involved animating my mother's face. I made this animation two years after her death. I digitally marked 
my work area this time, aiming to keep the animations to the correct ratio, but the images of my mother's face simply kept growing until they filled the screen available to my hands. Here are two more incidences of invisibility - the invisibility of grieving and the invisibility of the lost loved one's face.

The repeated wiping out and redrawing of her face was an act of grieving, a goodbye in each of the many thousands of fingertip strokes. That animation ended up being the wrong ratio also. So I experimented with various ways to deploy the animations on a different ratio, and I found that showing the animations as a window within a window, like a projection but also blended into the textures of the live action shot they occupied, actually added layers and nuances of meaning to the animation that I might not have uncovered without the serendipity of a technical mistake (Fig. 5).

\section{Conclusion}

The invisibility of radiation, of political manipulation, of memories, of lost medical notes, of science unfunded, of media unfunded, of raised blood sugar, of grieving and anxiety, of the lost loved one's face, of dust, of technical mistakes and failures are amongst the elements contributing to the ongoing story of Chernobyl Journey being made. Perhaps there should be parenthesis on the word made, as, although most certainly the film is being made and can be viewed privately, the way forward to the film possessing the status made and being publicly visible is not clear. At the time of writing the live action edit of Chernobyl Journey (using animatics in place of animations) is advanced. If Chernobyl Journey was a live action documentary, it could be finished within a few months. However, with one animator/compositor (myself) working on the animation alone and part-time (as, without a budget, it has to be) the film will still take years to make. So you could say, the animation is the problem. Delivering animation is usually at least either expensive or time-consuming, and very often both expensive and time-consuming - this is a problem for animation as an activist tool. My film is activist - it debunks the myth that nature will spring back like a lightly trodden on blade of grass, even after the worst excesses of human exploitation, extraction and environmental disaster, and records a counter history. But I am a poor animation activist - a character animator at heart, I work too slowly. I think the best kind of animation to deploy against neo-liberal ideas actually, paradoxically, conforms to the neo-liberal ideal of deliverology ${ }^{1}-$ to be independent enough to be subversive, but also speedy enough to get the work out there, when and where it is needed (that is now) - the animation eco-warrior needs to work both cheap, and fast.

However, in Chernobyl Journey animation explores and expresses memories, emotions and sensations; visualises radiation, links past and present, enhances science, satirizes political myths and is always subversively counter-historical; evoking a sense of tragedy and loss and anger, whilst also being the jester that laughs at everything and juggles all the layers into the air at once. Most importantly, animation easily transcends and unravels invisibility, transforming absence into presence. It is this quality that makes animation such a profoundly effective activist tool. As Bella Honess Roe states in Animated Documentary, "[t]here is a politics associated with visibility and, conversely, invisibility. To have a presence you must be visible. To have a say you must be both seen and heard" (Honess Roe, 2013, p. 87).

Because animation can empower by making visible, it is a tool that easily lends itself to subversive activism (and propaganda: the mechanism is the same but, differently motivated). From the earliest days of animation history, there has been an identification with politics and resistance: "Modernist theorists and artists were fascinated by cartoons. And those who took cartoons most seriously were political revolutionaries" (Esther, 2011, v)

1 "A method that uses inspections, goal setting, etc, to ensure that government departments implement desired reforms." (Wiktionary, free online dictionary.) 
The affinity of animation for subversion/propaganda has also been traced far back into the animation pre-history of cartoon and caricature, "historians often trace the first political cartoon back to 1360 BC in Egypt" (Herhuth, 2018, p. 170). In this extended history of animation activism, Chernobyl Journey represents an alternative dynamic from the proactively politically engaged cartoon - Chernobyl Journey has become an exercise in passively resisting invisibility, whilst also using invisibility as a survival tool. In Thesis 111 of his Theses on the Concept of History, Walter Benjamin writes: "The chronicler who narrates events without distinguishing between major and minor ones acts in accord with the following truth: nothing that has ever happened should be regarded as lost to history" (Löwy, 2016 p. 34) Chernobyl Journey tells my own story and as such, it is unimportant. But it is the nature of counter history to be minor and it is important that counter histories are recorded and shared because they are fragile and easily lost. I hope and aim to be able to show my finished film publicly someday, of course. But meantime there is value in using my animation art just to, as Benjamin writes in Thesis V11, "brush history against the grain" (Löwy, 2016, p. 47).

\section{Chernobyl Journey: Detailed Synopsis and Treatment}

Narrative: On $26^{\text {th }}$ April 1986, Reactor Number 4 at the Chernobyl Nuclear Power Plant in NE Ukraine exploded. A meltdown followed that lasted many days before the blaze was bought under control. Smoke containing radioactive ash was blown all around Europe by prevailing winds. In many locations, rain bought the ash down to the ground, especially on high ground. One of these areas was Snowdonia, the mountains of North Wales, where I now live. By the $2^{\text {nd }}$ of May 1986, the city of Pripyat and all the towns and villages within a 30K distance from the power plant had been evacuated. This was designated the Chernobyl Exclusion Zone (CEZ). In the late 1990s a small herd of extremely rare Przewalski Horses were released into the Ukrainian part of the Exclusion Zone. ${ }^{2}$ I first heard about the horses in 2008. I was looking for a new project for my paint on glass animation/live action collage technique. I went to the CEZ to research for a possible fiction from fact in 2009 but, as soon as I went through the first checkpoint into the Zone, I knew I was making a documentary. It took me seven years and three more visits to the Zone to work out why I needed to make a documentary.

In Chernobyl Journey live action footage is used to tell the story of my four trips to the Chernobyl Exclusion Zone between 2009 and 2015 in search of the rare Przewalski Horses. while animation unravels the story backwards, tracing my fascination for the Exclusion Zone to a life changing illness in my own timeline. This occurred after I had been walking in the rain that brought Chernobyl ash down on the mountains of North Wales in 1986. The memories of this illness were frozen in my mind. I could not consciously make a connection between my illness and Chernobyl but, instead, I felt compelled to visit the Zone. When, after my fourth trip to the Zone in 2015, I finally asked to see my medical notes for my illness of May to August 1986, the notes were found to be missing for the precise dates I had asked to see. A consultant's letter to my GP dated February 1987 confirmed that my notes were already missing by 1987 . But I have very strange memories of being acutely ill in hospital at that time. The memories account for only a few minutes of time, the rest of the three months is just a blackness of no consciousness, making a strange gap in my life. I decided to animate

2 The Przewalski Horses ('Takhi" in their native Mongolia) have a two-chromosome difference from domestic horses. Having been 'discovered' in the $19^{\text {th }}$ Century by the Russian explorer Nikolai Przewalski, they were hunted almost to extinction due to the Victorian passion for collecting. By the 1960s they were extinct in the wild and there were only 12 Przewalskis left scattered in zoos around the world. With the help of one domestic mare to improve the gene pool, the species was resurrected by a determined global breeding effort and by the 1990s there were several schemes to release them into the wild. A small herd of 28 horses was released from Askania Nova nature reserve in South Ukraine into the Chernobyl Exclusion Zone in 1998. 
my memories so that, in the absence of medical notes, there would be a record of my illness. In Chernobyl Journey the memories are revealed at the end, but they haunt the whole film with flickering images woven into the fabric of the Exclusion Zone that grow in intensity and length, as I gradually allow myself to think the taboo thought that there might be a connection between Chernobyl and my strange illness of May 1986.

The Animation: Animation is interwoven throughout Chernobyl Journey and entirely carries, along with my narrating voice, the 'real' or main psychological story of the film. Although there is presently a little more live action than animation in Chernobyl Journey, I see it as unquestionably an Animated Documentary (as opposed to a live action film with animated inserts) because animation is the strong narrative driving force in the film, and also because animation is interwoven into the live footage, becoming a part of the fabric of the two real landscapes that, along with my Inner-verse of memories, emotions and sensations, form the universe of the film. This woven-in nature of the animation in Chernobyl Journey problematizes the distinctions between animation and live action footage, between embodied experience and environment and between past and present. I use animation to show the difference between my traumatized memories and my usual experience of memory and consciousness, to reveal my memories of the past and to incorporate this past into the fabric of the film's present. In Animated Documentary Honess Roe describes this definitive fusion of animation and live photography as "a type of integration and cohesion, much like two chemical elements that have reacted to form a new substance from which neither original element could be extracted..." (Honess Roe 2013, p. 5) This describes very precisely the relationship between animation and live footage in Chernobyl Journey.
There are two fictional animated characters in Chernobyl Horses - an animated przewalski horse and a swallow. These fictional animated characters, that were created before the film was a documentary, transmute into aspects of myself in the documentary, although they are also still animals in themselves - they guide me on a shamanic journey into myself. This relationship is revealed via a series of metamorphoses from myself to swallow, from horse to swallow ${ }^{3}$ and back and finally from the horse to my young self of 1986 at the end of the film. It was not until after my final trip in 2015 that I made a conscious connection between my illness of 1986 and my compulsion to visit the CEZ, but the connection must have been already made subconsciously for me to feel so strongly compelled. So, these two animated characters represent a haunting by my past, the horse searches, the swallow makes leaps of faith, together they lead me towards a thought that is too politically taboo to be thought - that there might be some connection between my life changing illness and that ash-laden rain that came from Chernobyl. So, it is the animated characters that drive and enable the subversion in the film. There are many other animated animal characters in the film, and these have a dual purpose. They satirise the popular and highly political myth of wildlife 'thriving' in the CEZ. ${ }^{4}$ They also express nostalgia and longing and solidarity with the people and animals of the Zone and a wish that it was actually true that nature could just bounce back and recover, like a lightly trodden on blade of grass, after even the most devastating of environmental disasters caused by human activity.

Process: Although other techniques are already in place or planned in Chernobyl Journey, much of the animation so far is made using my primary technique of collaging paint on glass animals into live footage or animated backgrounds. I use simple materials - usually just one watercolour hue, sometimes

3 https://vimeo.com/561996887 This is the horse/swallow metamorphosis before rotoscope and compositing

4 Google 'Wildlife in Chernobyl' for multiple versions of the 'wildlife haven' narrative. Animals are in the Zone because they were put there by humans, or because humans can't keep them out and because animals cannot read books about the effects of radiation. The question of the welfare of these animals is complex, messy and disturbing. 
2, but never more than three, colours - and a white backlight under a flat glass frame. The animated image is captured digitally and then rotoscoped out of the white background and composited into a live image, with additional work to enhance its presence, such as shadows, light-wrap and light effects. My animal animation has a particular vitality that comes from the white background that glows through the watercolour paint in combination with my 'trick' of lightly touching all the paint, all over the animated animal, even if the character is still or almost still. This gives the animated image a directional flow that is different from the random boil often associated with handmade animation and works to bring the animated character to a strong illusion of 'life' and vitality. The fusion of animation and live action is also achieved by using After Effects blending modes that combine the textures and colours of the Zone with the textures and colours of the animation, this blending technique is usually applied with the memory animations. Another way the environment and animation are blended is through the printing of the film revealing radioactive particles onto transparent textile, as shown in Figure 3. A sample of the existing animations can be viewed here: https:// vimeo.com/showcase/8369637

\section{References}

Barad, K. (2007). Meeting the Universe Halfway: Quantum Physics and the Entanglement of Matter and Meaning. Durham, NC: Duke University Press.

Bennet, J. (2010). Vibrant Matter: a political ecology of things. Durham, NC: Duke University Press.

Bennet, J. (2010). A Vitalist Stopover on the Way to a New Materialism. In Coole, D and Frost, S. (Ed.), New Materialisms. Ontology, Agency, and Politics. Durham, NC: Duke University Press, pp. 1-43.
Buchan, S (Ed). (2013). 'Pervasive Animation.' London and New York, Routledge.

Coole, D and Frost, S. (2010). Introducing the New Materialisms. In Coole, D and Frost, S. (Ed.), New Materialisms. Ontology, Agency, and Politics. Durham, NC: Duke University Press, pp. 1-43.

Deleuze, G and Guattari, F. (2013). A Thousand Plateaus: Capitalism and Schizophrenia. London: Bloomsbury.

Esther, L. (2002). Hollywood Flatlands, Animation, Critical Theory and the Avant Garde London and New York: Verso

Gale, K. (2018). Madness as Methodology. Bringing Concepts to Life in Contemporary Theorising and Inquiry. London and New York: Routledge.

Haraway, D. (1997a). Simians, Cyborgs and Women: The Reinvention of Nature. London and New York: Routledge.

Halberstam, J. (2011). The Queer art of Failure. Durham and London: Duke University Press.

Herhuth, E. (2018). Political Animation and Propaganda. In Dobson, N; Ratelle, A; Honess Roe, A and Ruddell, C (Eds) The Animation Studies Reader. London and New York: Bloomsbury, pp. 169-179.

Honess Roe, A. (2013). 'The Animated Documentary'. Basingstoke: Palgrave Macmillan.

Ingold, T. (2013). 'Making: Anthropology, Archaeology, Art and Architecture'. London and New York: Routledge.

Lamarre, T (2013). Coming to life: cartoon animals and natural philosophy. In Pervasive Animation. Buchan, S (Ed). London and New York: Routledge, pp. 117-142. 
SHADES OF INVISIBILITY SALLY PEARCE

Löwy, M (2016). Fire Alarm: Reading Walter Benjamin's 'On the Concept of History'. London and New York: Verso.

Kuchinskaya, O. 2014. The Politics of Invisibility Cambridge, Ma and London, MIT press. 